\title{
Pendalilan Abdu Al Aziz Al Kināniy di Kitab Al Haydah Dalam Menetapkan Akidah Al Qur'an Kalam Allah
}

\author{
Mubarak Bamualim \\ STAI Ali Bin Abi Thalib Surabaya \\ mubarakbamualim1965@gmail.com
}

\begin{abstract}
Abstrak
Sebaik-baik zaman adalah tiga generasi pertama: zaman kenabian, zaman sahabat dan zaman tabi'in, pada zaman ini belum terjadi perbedaan pendapat di dalam masalah pokok akidah. Pada zaman Nabi dan dua khalifah al räshidin belum muncul kelompok-kelompok menyimpang. Di akhir kekuasaan Uthmān muncul kelompok khawārij, kemudian pada zaman Ali muncul kelompok Rāfị̣ah dan seterusnya muncullah kelompok-kelompok yang lainnya seperti Qadariyyah, Jabariyyah, Mu'tazilah dan jahmiyyah. ${ }^{1}$ Kelompok-kelompok tersebut mencetuskan akidah-akidah baru yang belum pernah dinukilkan dari Nabi dan para sahabat beliau, diantara akidah baru yang berkembang dan dimunculkan Jahmiyyah adalah akidah al qur'ān adalah makhluk. Akidah ini menjadi akidah negara pada masa dinasti Abbāsiyyah, tercatat dalam sejarah tiga khalifah Abbāsiyyah yang memaksakan akidah ini untuk dianut oleh umat Islam saat itu, mereka adalah: al Ma'mūn, al Mu'tashim, dan al Wäthiq. Meskipun demikian terdapat ulama yang menentang akidah tersebut diantaranya adalah $A b d u$ al 'aziz al Kināniy, pertentangannya terhadap akidah al Qur'ān makhluk tergambar jelas dalam buku beliau al Haydah. Pada penelitian ini penulis mencoba untuk mengeksploit asi tentang dalil-dalil yang digunakan oleh 'Abdu al azīz al kināniy di dalam menetapkan akidah al Qur'an kalām Allah. Setelah menganalisa kitab tersebut penulis mendapati bahwa 'Abdu al azīz al kināniy di dalam menetapkan akidah al Qur'an kalām
\end{abstract}

1 Muhammad bin Solih al Uthaimin, Taqrīb al Tadmuriyyah, (Unaizah: Madār al Wațan, 2009), h.5-7 
Mubarak Bamualim

Allah berdalil dengan tiga pendalilan, yang pertama adalah al Qur'ān, yang kedua adalah logika dan yang ketiga adalah analogi.

Kata kunci: Pendalilan, Abdu al azỉz al kināniy, al Qur'ān. Kalām Allah. Makhluk.

\section{A. Pendahuluan}

Al Qur'ān adalah kitab suci umat Islam, al Qur'ān merupakan kitab yang berisikan petunjuk, di dalam al Qur'ān terdapat segala sesuatu yang dibutuhkan manusia unt uk menjalani kehidupan dunia dan keselamatan di alam akhirat. Allah telah berjanji untuk menjaga al Qur'ān sehingga siapa saja yang berusaha unt uk merubah al Qur'ān baik berupa merubah huruf atau kata dalam al Qur'ānniscaya akan diketahui.

Diantara bentuk kesalahan yang terkait dengan al Qur'ān adalah pendapat dan keyakinan yang mengatakan bahwa al Qur'ān adalah makhluk bukan kalām Allah. Pendapat ini telah banyak dibantah oleh para ulama semenjak awal kemunculannya, diantara ulama yang membantah pendapat ini adalah $A b d u$ al Azíz al Kināniy di dalam kitab beliau al Haydah.

\section{B. Kitab Al Haydah}

Kitab al Haydahberisikan tentang perdebat an yang dilakukan oleh Abdu al Azíz al Kināniy dengan Bishr al Mirisiy di hadapan khalifah al Abbāsiyyah pada saat itu al Ma'mün, tema perdebatan seputar apakah al Qur'ān kalām Allah atau makhluk.

Terdapat dua point penting yang berkaitan dengan kitab al Haydah: yang pertama mengenai kefaktaan perdebatan antara $A b d u$ al Azíz al Kināniy dengan Bishr al Mirisiy, point kedua adalah kebenaran penisbatan kitab al Haydah kepada Abdu al Azīz al Kināniy.

Para ulama telah bersepakat tentang kefaktaan dialog antara $A b d u$ al Azìz al Kināniy dengan Bishr al Mirisiy seputar penciptaan al Qur'ān, 


\section{Pendalilan $A b d u$ Al Aziz Al Kināniy di Kitab Al Haydah}

tidak ada ulama yang mengingkati penisbatan kitab tersebut kepada Abdu al Azīz al Kināniy kecuali al Imām al Dzahabiy dan al Subkiy.

Berkata Shaikh Dr Ali bin Muhammad bin Nāsir al faqīh:

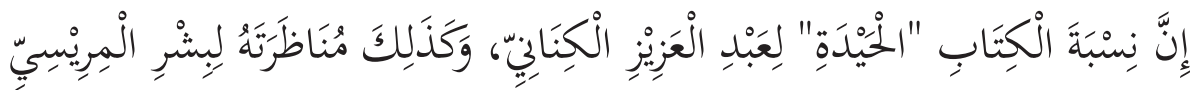

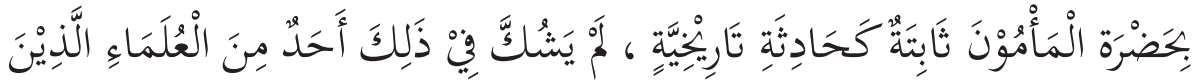

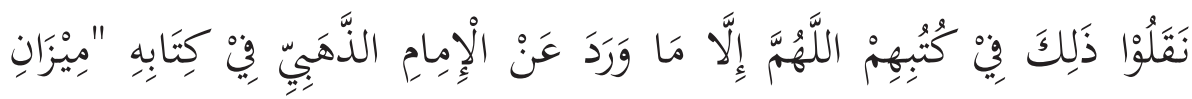
الْالِعتِدَالِ" مِنْ حَيْثُ إِسْنَادُ الْكِتَابِ....

Sesungguhnya penisbatan kitab "al Haydah"kepada Abdu al Aziz al Kināniy, begitu juga dengan perdebatan beliau dengan Bishr al Mirisiy di hadapan al Ma'mūn merupakan kejadian yang benar-benar terjadi sebagaimna kejadian sejarah yang lainnya, tidak ada satupun ulama yang menukil kisah ini di kitab-kitab mereka meragukan kefaktaan perdebatan ini kecuali apa yang datang dari al Imām al Dhahabiydalam kitab mìzān al i'tidāl, beliau meragukan sanad kitab ini".

Akan tetapi di dalam kitab beliau yang lain, al Imām al Dhahabiy berkata:

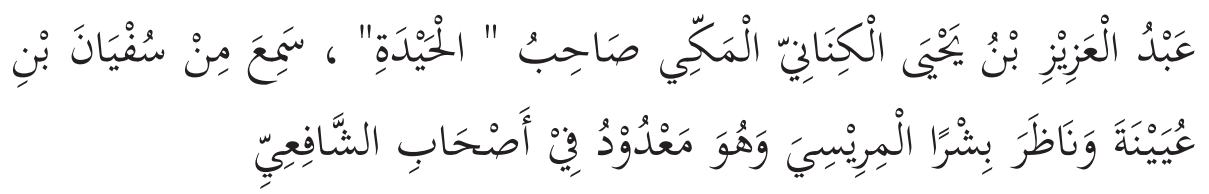

Dan Abdu al Azīz bin Yahyā al Kināniy al Makkiy pemilik kitab al Haydah, dia mendengar dari Sufyān bin 'Uyainah dan mendebat Bishr

2 Abdu al Azīz al Kināniy, Al Haydah al Munāzarah al Kubrā Baina Ahlu al Sunnah wa al Firaq al Dāllah tahqìq Dr Ali bin Muhammad al Faqīh, (Kairoh: Där al Furqān, 2009), 6. 
al Mirisiy, Abdu al Azīz bin al Kināniy termasuk murid dari Imām al Shäfi'iy. ${ }^{3}$

Selain diingkari oleh al Dhahabiy kefaktaan kitab al haydah juga diingkari oleh al Subkiy, meskipun demikian al Subkiy tetap mengakui adanya dialog atau perdebatan antara Abdu al Azíz bin al Kināniy dengan Bishr al Mirisiy.

Secara garis besar dapat disimpulkan bahwa penolakan al Imām al Dhahabiy terhadap penisbatan kitab al haydah kepada Aziz bin al Kināniy dilandasi dua hal: yang pertama adanya räwi yang tertuduh sebagai pemalsu atau dikenal dengan suka memalsukan hadis. Adapaun alasan kedua bahwa seandainya dialog ini benar-benar terjadi tentunya al Ma'mūn akan meninggalkan pemahaman al Qur'ān adalah makhluk, namun realitanya meskipun al Ma'mün menghadiri dialog tersebut dan menyaksikan bahwa Bishr al Mirisiy. tidak bisa menjawab dalil-dalil yang disampaikan oleh Abdu al Azīz bin al Kināniy.

Dr Ali bin Muhammad bin Nāsir al Faqīh telah menjawab alasan yang disampaikan oleh al Imām al Dhahabiy, berikut ini jawaban atau tanggapan dari ucapan al Imām al Dhahabiy.

"Berkaitan dengan sanad kitab yang dikritik oleh al Imām al Dhahabiy, disebabkan adanya rawi kitab yang tertuduh pemalsu hadis, Dr Ali bin Muḥammad bin Nāṣir al Faqīh menjawab bahwa keraguan ini terbantahkan jika didapatkan sanad lain selain sanad yang disampaikan oleh al Imām al Dhahabiy".

Berikut ini nukilan sanad kitab yang dimaksud oleh al Imām al Dhahabiy:

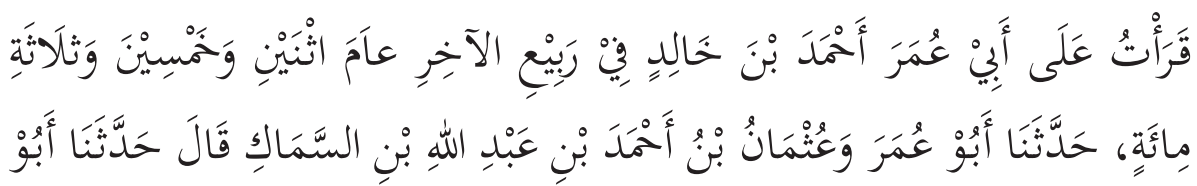

3 Muhammad bin Ahmad al Dhahabiy, al 'Ibar fii al Khabar Man Ghabar, (Beirut: Dār al Kutub al Ilmiyyah, Beirut, tanpa menyebutkan tahun terbit), 1/341. 


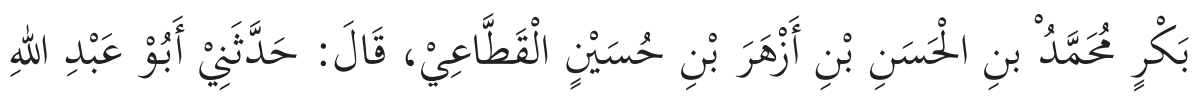

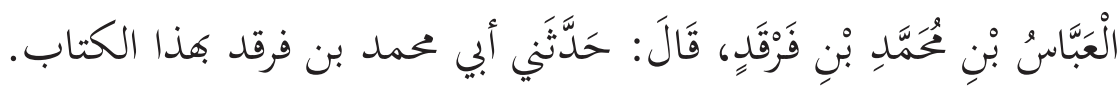

"Aku membaca di hadapan $A b u$ 'Umar Ahmad bin Khälid pada bulan Rabi'ul Akhir tahun $352 \mathrm{H}$, menceritakan kepada kami $A b u$ 'Amr Uthmān bin Ahmad bin Abdillah bin al Sammāk dia berkata: menceritakan kepadaku Abu Bakr Muhammad bin al Hasan bin Azhar bin al Husain al Qatayā'iy dia berkata: menceritakan kepadaku Abdullah bin al Abbās bin Muhammad bin Farqad dia berkata menceritakan kepadaku Abu Muhammad bin Farqad kitab ini dari awal sampai akhir dia berkata, berkata Abdu al Azíz bin al Kināniy ". ${ }_{4}$

al Imām al Dhahabiy mengingkari penisbatan kitab al Haydah kepada $A b d u$ al Azīz bin al Kināniy dikarenakan dalam sanad tersebut terdapat rāwi yang nama Abu Bakr Muhammad bin al Hasan Azhar, dialah yang tertuduh sebagai wadd $\vec{a}$ (suka memalsukan hadits).

Pendapat al Imām al Dhahabiy terbantahkan dengan ditemukannya sanad lain selain sanad di atas. Al Imām Ibnu Battah di dalam kitab al Ibānah membawakan sanad lain, beliau berkata:

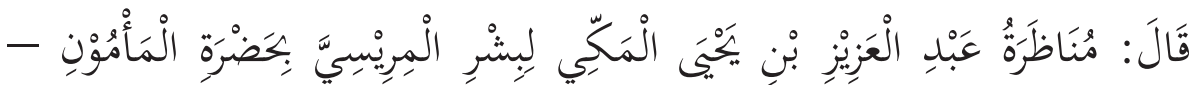

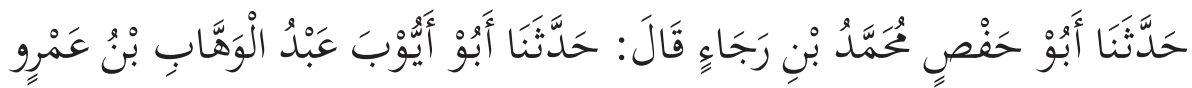

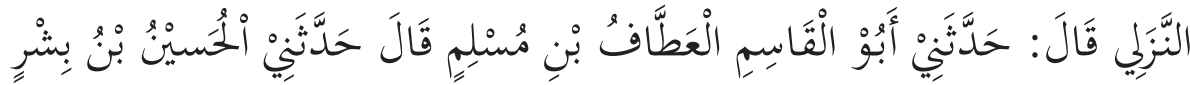

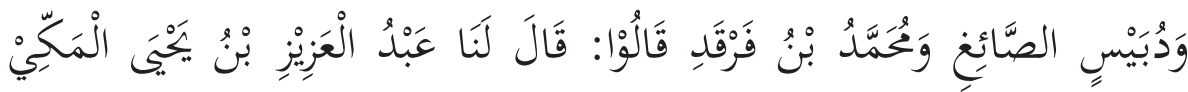
الْكِنَانِ.

4 Abdu al Azīz al Kināniy, Al Haydah al Munāzarah al Kubrā Baina Ahlu al Sunnah wa al Firaq al Dāllah tahqīq Dr Ali bin Muhammad al Faqīh, 20 
(Ibnu Battah) berkata: "Perdebatan Abdu al Azizz bin Yahya al Makkiy dengan Bishr al Mirisiy. dihadapan al Ma'mūn, Abu Hafsh Muhammad bin Rajā menceritakan kepadaku, Abu Ayub Abdu al Wahhāb 'Amr al Nazaliy menceritakan kepadaku, dia berkata: Abu al Qāsim al 'A țtäf bin Muslim menceritakan kepadaku, dia berkata: al Husain bin Bishr dan Dubays al Säigh dan Muhammad bi Farqad menceritakan kepadaku, mereka berkata: berkata kepada kami $A b d u$ al Azìz bin al Kinäniy" "'s

Dengan adanya sanad dari Ibnu Battah maka anggapan bahwa kitab tersebut tidak bisa disandarkan kepada $A b d u$ al $A z \bar{z} z$ bin al Kināniy tidak dapat dijadikan hujjah.

Dasar kedua yang dijadikan al Imām al Dhahabiy adalah ketidak rujukkannya al ma'mūn kepada akidah al Qur'ān kaläm Allah padahal dia telah menyaksikan perdebatan antara Abdu al Azíz al Kināniy dan Bishr al Mirisiy. Dan dia telah menget ahui bahwa Bishr al Mirisiytidak bisa membantah semua argumen yang disampaikan oleh $A b d u$ al Azíz al Kināniȳ, ini semua dikarenakan kuatnya shubhät al Jahmiyyahyang ada pada al ma'mūn sehingga shubhät itu menjadi akidah.

Atas dasar ini pendapat dari al Imām al Dhahabiy bahwa kitab al Haydah bukan tulisan Abdu al Azìz al Kināniy merupakan pendapat yang lemah, terlebih banyak ulama menetapkan bahwa kitab al Haydah merupakan tulisan dari Abdu al Azīz al Kinānī̄ .

al Imām ibnu kathïr berkata:
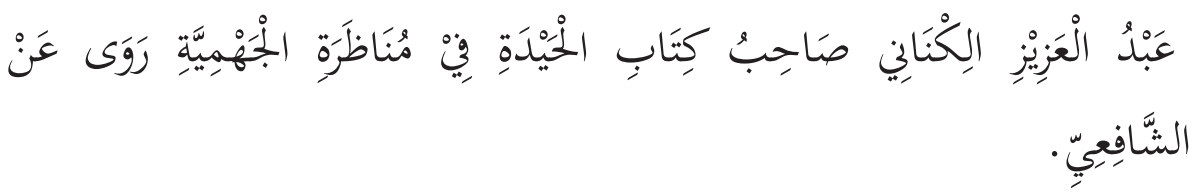

5 Ibnu Battah, al Ibānah 'an al Sharì' ati al Firqah al Nājiyyah wa Mujanābah al Firaq al Dhālah, (Riyadh: Dār al Rāyah, 418H). 2/227. 


\section{Pendalilan $A b d u$ Al Aziz Al Kināniy di Kitab Al Haydah}

“Abdu al Azīz al Kināniȳ penulis kitab al Haydah tentang perdebatan (beliau) dengan al Jahmiyyah, (beliau) meriwayatkan dari al Shäfi 'iy. ${ }^{6}$

Ibnu Hajar al Asqalāniy berkata:

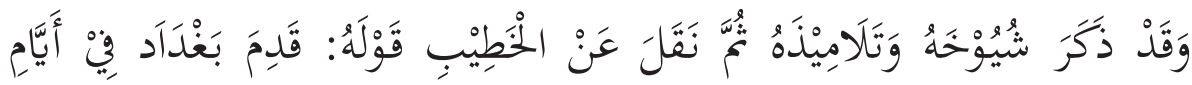

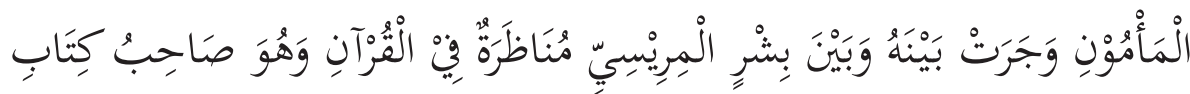

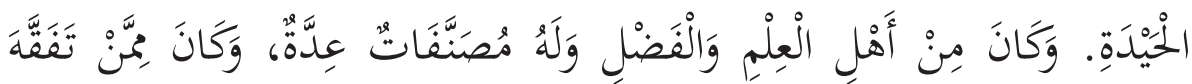

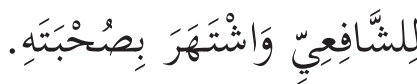

"Dan sungguh (Ibnu Hajar) telah menyebutkan para gurunya dan muridnya, kemudian dia menukil ucapan al Khatīb: "Abdu al Aziz al Kināniy datang ke Baghdad pada masa pemerintahan al Ma'mün, terjadi debat antara dia dan Bishr al Mirisiy tentang al Qur'ān, beliau adalah penulis kitab al Haydah dan termasuk ahli ilmu dan keutaan, beliau memiliki banyak karangan dan termasuk murid dan sahabat dari al Imām al Shäfi'iy"?

al Imām Ibnu Abi al 'izz al Hanafiy berkata:

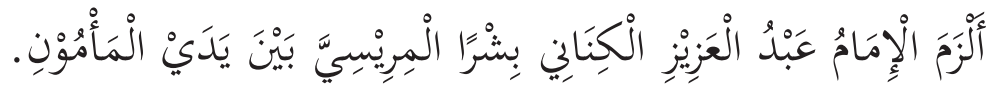

“ Al Imām Abdu al Azīz al Kināniỳ telah membungkam Bishr al Mirisiy di hadapan al Ma'mūn".

6 Ismā'il bin Umar Ibnu Kathīr, Tabaqāt al Shäfi'iyyah Taḥqìq 'Abdu al Hafiz, (Beirut: Dār al Madār al Islāmiy,2004), 1/147.

7 Ahmad bin Ali al Asqalāniy, Tahdỉb al Tahdhïb, (Riyadh: al Muassah al Risālah,tanpa menyebutkan tahun), 2/598.

8 Ali bin Ali bin Muhammad bin Abi al 'Izz al Ḥanafiy, Sharh al Ṭahāwiyyah Fỉ al Aqīiah al Salafiyyah,(Riyadh: Wizārah al Shu'ūn al Islāmiyyah wa al Auqāf wa al Da'wah wa al Irshad,1418 H), 133. 
Mubarak Bamualim

\section{Biografi $A b d u$ Al Aziz Al Kināniy}

\section{Nama dan Nasab}

Nama beliau adalah $A b d u$ al Azīz al Kināniy bin Yahyā bin Abdu al Azīz bin Muslim bin Maymūn al Kināniy al Makkiy. beliau berasal dari suku kinanah. ${ }^{9}$ Para ulama sejarah tidak menyebutkan tahun kelahiran beliau.

Abdu al Azīz al Kināniy merupakan ulama besar, beliau termasuk salah satu murid al Imām al Shāfi'iy., beliau begitu lama menemani al Imām al Shäfíiy., Abdu al Azīz al Kināniy pernah menemani al Imām al Shäfi 'iy dalam perjalanan ke negeri Yaman dan kembali lagi ke Mekkah, maka tidaklah mengherankan jika al Imām al Shāfi'iy sangat mempengaruhi kehidupan beliau, pengaruh al Imām al Shäfi'iy begitu jelas di tulisan-tulisan $A b d u$ al $A z \bar{i} z$ al Kināniy terlebih dalam membahas bab umum, khusus dan al bayān. ${ }^{10}$

\section{Guru dan Murid}

Selain dari al Imām al Shăfi 'iybeliau juga mengambil ilmu dari ulama-ulama lain diantaranya: Hishām bin Sulaimān al Makhzūmiy, Marwān bin Mu'àwiyah al fazzāryi, Sufyān bin 'Uyainah dan lain sebagainya.

Dan diantara ulama yang meriwayatkan dari beliau adalah Abu al 'Aynā' Muhammad bin al Qāsim bin khallād, Abu Bakr Ya'qūb bin Ibrāhìm at Taiymiy dan al Husaiyn bin al Fadl al Bajaliy. ${ }^{11}$

9 Abdu al Azīz al Kināniy, Al Haydah tahqīq jamīi șaliban, (Damaskus: matbū'àt al majāmi' al 'ilmy al Araby, 1964), 9.

10 Ibid., 9

11 Abu al Ḥajāj Yusuf al Mizziy, Tahdhīb al Kamāl, (Beirut: Dār al Fikr,1994), 11/543. 


\section{Pendalilan Abdu Al Aziz Al Kināniy di Kitab Al Haydah}

\section{Perdebatan dengan Bishr al Mirisiy}

Di awal kitab al haydah, Abdu al Azīz al Kināniy menceritakan sebab terjadinya perdebatan antara dia dengan Bishr al Mirisiy, pada zaman beliau tersebar akidah yang diusung oleh sekte al Jahmiyyah, akidah tersebut berupah keyakinan bahwa al Qur'ān adalah makhluk bukan kalām Allah, akidah ini menjadi akidah negara dan didukung oleh pemerintah. Manusia-manusia ditimpa ketakutan, sebagian meninggalkan negeri mereka dan banyak yang mengunci diri di rumah tidak mau berkumpul dengan sesama.

Sampailah kabar tersebut ketelinga $A b d u$ al $A z \bar{z} z$ al Kināniy, maka beliaupun bertekad unt uk pergi ke kota Baghdad, beliau ingin berdebat dengan tokoh sekte Jahmiyyah pada saat itu. Beliau sembunyikan keinginan tersebut, dan berdo'a kepada Allah agar dibukakan pemahaman terhadap ayat-ayat-Nya, dimudahkan lisannya untuk menjelaskan apa yang terkandung di dalam al Qur'ān, akhirnya beliaupun datang ke kota Baghdad.

Ketika hari jum'at pada awal-awal kedatangan beliau di kota Baghdad, beliau bertekad untuk mengumumkan dihadapan manusia mengenai keyakinan beliau terhadap al Qur'ān. Beliaupun sholat jum'at di masjid al Jämi'dan duduk di barisan pertama, ketika imam selesai salam beliaupun berdiri agar semua manusia bisa melihat dan mendengar, beliaupun mengangkat suara dengan lantangnya: "Wahai anakku apa pendapatmu tentang al qur'ān ?" dia menjawab: "kalām Allah dan bukan makhluk".

Atas perbuatannya $A b d u$ al Azīz al Kināniy, ditangkap oleh pihak pemerintahan dan dibawa kehadapan khalifah al Ma'mūn, ketika berada di hadapan al ma'mūn, Abdu al Azíz al Kināniy, menjelaskan maksud dari apa yang beliau lakukan di masjid al Jämi', beliau ingin berdialog dengan Bishr al Mirisiy. Al ma'mün akhirnya mengizinkan beliau untuk berdebat dengan 
Mubarak Bamualim

Bishr al Mirisiydan beliau sendiri yang menjadi penengah antara keduanya. $^{12}$

\section{Wafat}

al Imām al Dhahabiy menjelaskan di dalam kitab al 'Ibar bahwa Abdul Aziz al Kinani wafat di tahun 240 an dari tahun Hijriyyah. ${ }^{13}$

\section{Pendalilan Abdu Al Aziz Al Kināniy di Kitab Al Ḥaydah Dalam Menetapkan Akidah Al Qur'an Kalam Allah}

Di dalam kitab al haidah Abdu al Azíz al Kināniy menyebutkan beberapa pendalilan untuk menetapkan akidah al qur'an kalamullah, diantaranya;

\section{Al Qur'ān}

Untuk menetapkan akidah al Qur'ān kalām Allah, Abdu al Azīz al Kināniy melakukan beberapa langkah berikut:

a. Menetapkan sifat kalām bagi Allah

Allah berfirman

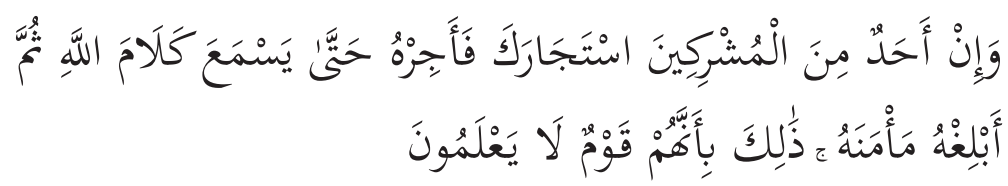

"Dan jika seorang diantara orang-orang musyrikin itu meminta perlindungan kepadamu, maka lindungilah ia supaya ia sempat mendengar firman Allah, kemudian

12 Abdu al Azīz al Kināniy, Al Haydah al Munāzarah al Kubrā Baina Ahlu al Sunnah wa al Firaq al Ḍāllah tahqīq Dr Ali bin Muḥammad al Faqīh, (Kairo: Dār al Furqān, 2009), 9

13 al Imām al Dhahabiy, al "Ibar (......) 


\section{Pendalilan $A b d u$ Al Aziz Al Kināniy di Kitab Al Haydah}

antarkanlah ia ke tempat yang aman baginya. Demikian itu disebabkan mereka kaum yang tidak mengetahui". ${ }^{14}$

Allah berfirman:

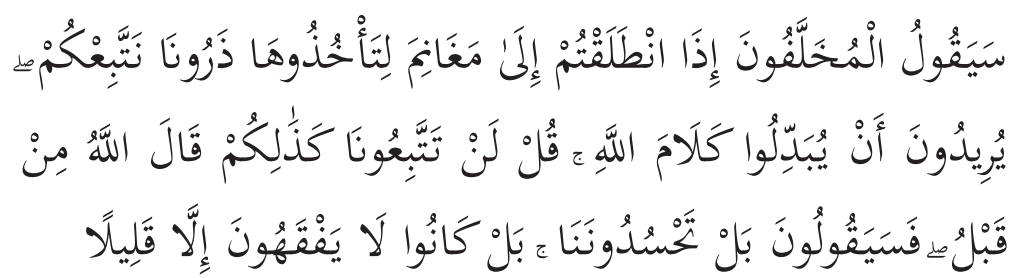

"Orang-orang Badwi yang tertinggal itu akan berkata apabila kamu berangkat untuk mengambil barang rampasan: "Biarkanlah kami, niscaya kami mengikuti kamu"; mereka hendak merubah janji Allah. Katakanlah: "Kamu sekali-kali tidak (boleh) mengikuti kami; demikian Allah telah menetapkan sebelumnya"; mereka akan mengatakan: "Sebenarnya kamu dengki kepada kami". Bahkan mereka tidak mengerti melainkan sedikit sekali". ${ }^{15}$

b. Menetapkan bahwa al Qur'ān adalah al Haq

Ada beberapa ayat yang dijadikan dalil diantaranya:

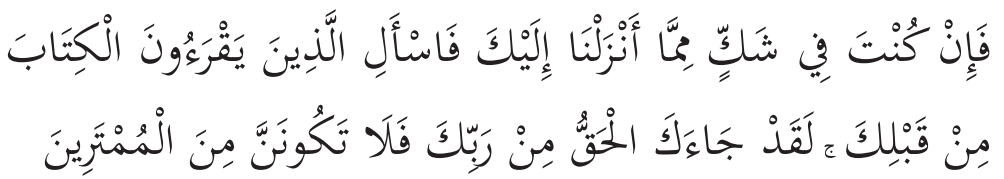

"Maka jika kamu (Muhammad) berada dalam keraguraguan tentang apa yang Kami turunkan kepadamu, maka tanyakanlah kepada orang-orang yang membaca kitab sebelum kamu. Sesungguhnya telah datang kebenaran

14 QS. Al-Taubah (9): 6.

15 QS. Al-Fath. (48): 15. 
$\checkmark$ Mubarak Bamualim

kepadamu dari Tuhanmu, sebab itu janganlah sekali-kali kamu termasuk orang-orang yang ragu-ragu". ${ }^{16}$

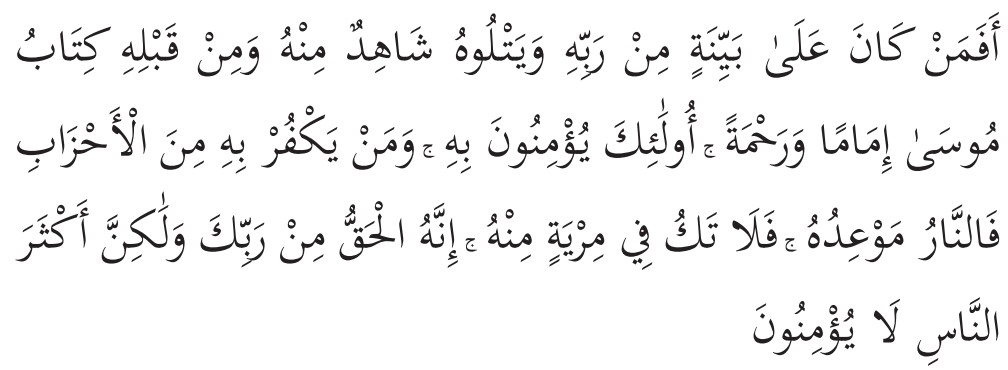

“Apakah (orang-orang kafir itu sama dengan) orangorang yang ada mempunyai bukti yang nyata (al Qur'ān) dari Tuhannya, dan diikuti pula oleh seorang saksi (Muhammad) dari Allah dan sebelum al Qur'ān itu telah ada Kitab Müsá yang menjadi pedoman dan rahmat? Mereka itu beriman kepada al Qur'ān. Dan barangsiapa di antara mereka (orangorang Quraisy) dan sekutu-sekutunya yang kafir kepada al Qur'ān, maka nerakalah tempat yang diancamkan baginya, karena itu janganlah kamu ragu-ragu terhadap al Qur'ān itu. Sesungguhnya (al Qur'ān) itu benar-benar dari Tuhanmu, tetapi kebanyakan manusia tidak beriman". ${ }^{17}$

c. Menjelaskan bahwa al Qur'ān adalah al Qaul (ucapan)

Setelah mendatangkan ayat-ayat yang menerangkan bahwa al Qur'ān adalah al haq, kemudian Abdu al Azíz al Kināniy membawakan bahwa al Qur'ān adalah al Qaul (ucapan), beliau membawakan beberapa dalil diantaranya:

16 QS. Yunus (12): 94.

17 QS. Hud (11): 17. 


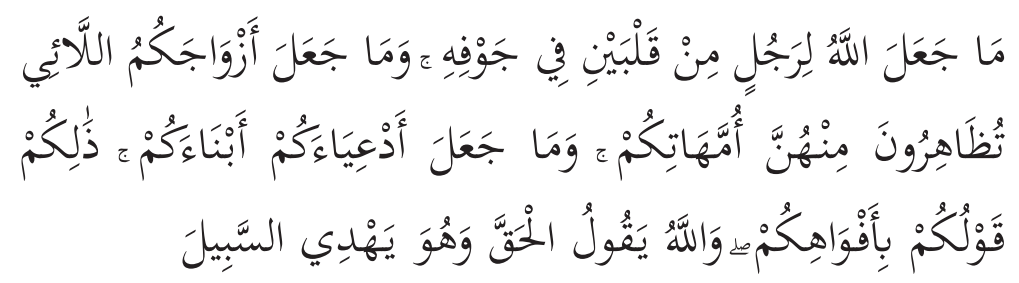

"Allah sekali-kali tidak menjadikan bagi seseorang dua buah hati dalam rongganya; dan Dia tidak menjadikan istriistrimu yang kamu zhihar itu sebagai ibumu, dan Dia tidak menjadikan anak-anak angkatmu sebagai anak kandungmu (sendiri). Yang demikian itu hanyalah perkataanmu di mulutmu saja. Dan Allah mengatakan yang sebenarnya dan Dia menunjukkan jalan (yang benar)" ${ }^{18}$

Allah berfirman:

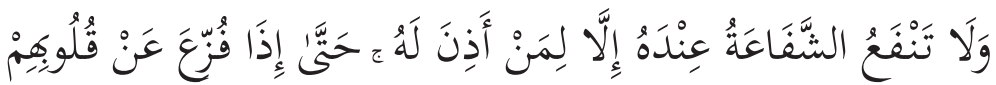

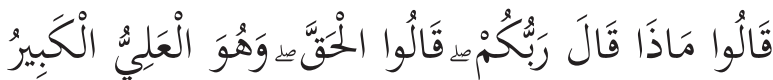

"Dan tiadalah berguna syafa'at di sisi Allah melainkan bagi orang yang telah diizinkan-Nya memperoleh syafa'at itu, sehingga apabila telah dihilangkan ketakutan dari hati mereka, mereka berkata "Apakah yang telah difirmankan oleh Tuhan-mu?" Mereka menjawab: (Perkataan) yang benar", dan Dialah Yang Maha Tinggi lagi Maha Besar". ${ }^{19}$

d. Menyebutkan bahwa al Qur'ān adalah amrullah.

Allah berfirman:

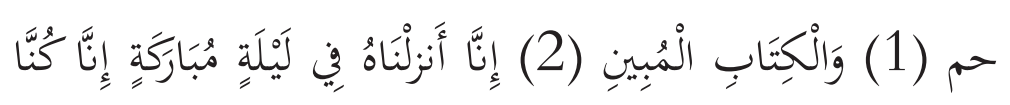

18 QS. Al-Aḥzāb(33): 4.

19 QS. Saba: (34): 23. 
Mubarak Bamualim

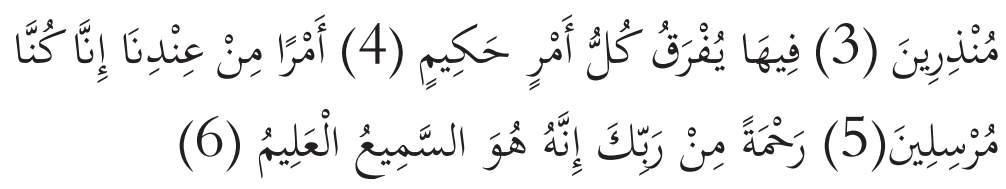

'Ha Mim. Demi Kitab (al Qur'ān) yang menjelaskan, sesungguhnya Kami menurunkannya pada suatu malam yang diberkahi dan sesungguhnya Kamilah yang memberi peringatan. Pada malam itu dijelaskan segala urusan yang penuh hikmah, (yaitu) urusan yang besar dari sisi Kami. Sesungguhnya Kami adalah Yang mengutus rasul-rasul, sebagai rahmat dari Tuhanmu. Sesungguhnya Dialah Yang Maha Mendengar lagi Maha mengetahui" ${ }^{20}$

Allah berfirman:

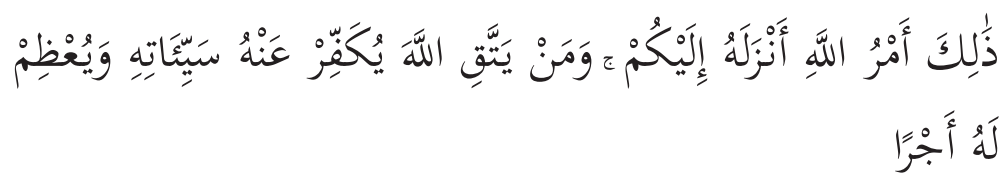

"Itulah perintah Allah yang diturunkan-Nya kepada kamu, dan barangsiapa yang bertakwa kepada Allah, niscaya Dia akan menghapus kesalahan-kesalahannya dan akan melipat gandakan pahala baginya". ${ }^{21}$

'Abdu al Azīz al Kināniy berkata menerangkan ayat tersebut: " yaitu al Qur'ān dan ini merupakan kabar Allah bahwa al Qur'ān adalah amru (perkara ) Allah, dan amru (perkara ) Allah adalah al Qur'ān. ${ }^{22}$

20 QS. Al-Dukhān (44): 1-6

21 QS. Al-Ṭalāq. (65): 5.

22 Abdu al Azīz al Kināniy, Al Haydah al Munāzarah al Kubrā Baina Ahlu al Sunnah wa al Firaq al Ḍällah tahqīq Dr Ali bin Muhammad al Faqīh, 41. 


\section{Pendalilan Abdu Al Azīz Al Kināniy di Kitab Al Haydah}

\section{Logika}

Penggunaan dalil dengan akal digunakan $A b d u$ al Azíz al Kināniy setelah dia berhasil mematahkan argument-argument Bishr al Mirisiy yang disandarkan pada ayat al Qur'ān. Ketika Bishr al Mirisiy tersudutkan dia menginginkan agar debat selanjutnya menggunakan logika.

Abdu al Azīz al Kināniy menjelaskan bahwa keyakinan al Qur'ān adalah makhluk tidak akan keluar dari tiga hal: yang pertama bahwa Allah menciptakan al Qur' an di dalam dirinya, yang kedua Allah menciptakan al Qur'ān dalam diri makhlukmakhluknya dan yang ketiga bahwa Allah menciptakan al Qur'ān secara independen.

Ketiga hal di atas ditanyakan Abdu al Azïz al Kināniy kepada Bishr al Mirisiy, akan tetapi Bishr al Mirisiy tidak berani untuk menjawab atau memilih salah satu dari pilihan yang diberikan $A b d u$ al Aziz al Kināniy, hal ini didasari karena Bishr al Mirisiy paham kemana arah yang diinginkan $A b d u$ al Aziz al Kināniy.

Kemungkinan pertama merupakan sesuatu yang mustahil, karena tidak mungkin Allah menciptakan makhluk yang berada di dalam dzat-Nya, kemungkinan kedua Allah menciptakan al Qur'ān di dalam makhluknya maka ini berkonsekuensi bahwa segala sesuatu yang dikatakan makhluk adalah al Qur'ān, dan kemungkinan ketiga bahwa jika Allah menciptakan al Qur'ān secara independen maka hal ini tidak mungkin; karena setiap ucapan pasti ada yang mengucapkan.

Dalil logika yang disampaikan $A b d u$ al Azíz al Kināniy yang lain berupa ucapan beliau berikut:

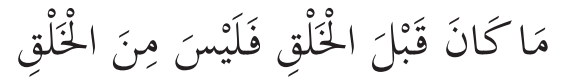

"Segala sesuatu yang telah ada sebelum penciptaan maka 
dia bukan makhluk"23

Maksud dari ucapan ini adalah bahwasanya Allah ada sebelum adanya segala sesuatu, kemudian Allah menciptakan (mengadakan) sesuatu tersebut. Allah mengadakan sesuatu (makhluk) dengan kekuasaan-Nya, keinginan-Nya dan ucapanNya. Sementara al Qur'ān adalah ucapan Allah dan ucapan Allah ada sebelum Allah menciptakan segala sesuatu, atas dasar ini al Qur'ān bukan makhluk, karena jika al Qur'ān adalah makhluk maka dengan apa Allah menciptakan al Qur'ān.

\section{Analogi}

Abdu al Azìz al Kināniymenganalogikan antara al Qur'ān dan Penciptaan dengan dua orang anak yang dimiliki oleh Bishr al Mirisiy. tidak ada yang menget ahui dan membedakan mereka berdua kecuali Bishr al Mirisiy, dikatakan yang pertama bernama Khalid dan yang kedua bernama yazid.

Suatu ketika Bishr al Mirisiy menulis delapan belas surat kepada $A b d u$ al Azīz al Kināniy, di setiap surat dia berkata: "berikan Surat ini kepada anakku yang bernama Khalid. Kemudian dia menulis surat lagi untukku sebanyak 54 surat, di setiap surat dia berkata: "berikan kepada Yazid (dia tidak menyebut Yazid anakku)", kemudian Bishr al Mirisiy menulis satu surat, di surat tersebut dia berkata: "berikan ini kepada anakku yang bernama Khalid, dan berikan kepada Yazid (tanpa menyebut anakku).

Allah telah mengabarkan di dalam al Qur'ān bahwa dia menyebutkan penciptaan di delapan belas ayat, dan menyebut al Qur'ān di lima puluh empat ayat, kemudian menyebutkan keduanya di satu ayat, jika seandainya al Qur'ān adalah makhluk tentu Allah akan menyebutkannya di dalam al Qur'ān, akan

23 Ibid, 83 


\section{Pendalilan Abdu Al Azīz Al Kināniy di Kitab Al Haydah}

tetapi sebaliknya justru ketika Allah menyebutkan penciptaan manusia dan al Qur'ān Allah tidak menyandarkan penciptaan kepada al Qur'ān.

\section{E. Kesimpulan}

Dari paparan di atas kita pahami bahwa dalam menetapkan akidah al Qur'ān kalām Allah Abdu al Azíz al Kināniymenggunakan tiga dalil, yang pertama adalah dalil al Qur'ān, pendalilan dengan al Qur'ān dengan cara menetapkan sifat kalām bagi Allah, menyebutkan ayat-ayat bahwa al Qur'ān adalah al Haq dan amru Allah kemudian menerangkan bahwa keduanya adalah ucapan Allah, yang kedua dalil logika dan yang ketiga dalil analogi.

\section{F. Daftar Pustaka}

Al Qur'ān al Karìm

(al) Asqalāniy Ahmad bin Ali, tanpa menyebutkan tahun, Tahdib al Tahdhīb, Riyadh: al Muassah al Risālah.

Battah, Ibnu, 1418H, al Ibānah 'an al Sharì' ati al Firqah al Nājiyyah wa Mujanābah al Firaq al Dhālah, Riyadh: Dār al Rāyah.

(al) Dhahabiy, Muhammad bin Ahmad, tanpa menyebut tahun terbit, al 'Ibar fii al Khabar Man Ghabar, Beirut: Dār al Kutub al Ilmiyyah, Beirut.

(al) Hanafiy, Ali bin Ali bin Muhammad bin Abi al 'Izz, 1418 H, Sharh al Țahāwiyyah Fī al Aqīdah al Salafiyyah, Riyadh: Wizārah al Shu'ūn al Islāmiyyah wa al Auqāf wa al Da'wah wa al Irshād.

(al ) Kināniy, Abdu al Azīz, 1964, Al Hụdah tahqīq jamīl ṣaliban, Damaskus: matbū'àt al majāmi' al 'ilmy al Arabiy.

(al) Kināniy, Abdu al Azīz, 2009, Al Haydah al Munāzarah al Kubrā Baina Ahlu al Sunnah wa al Firaq al Dällah tahqiq Dr Ali bin Muhammad al Faqīh, Kairo: Dār al Furqān. 
- Mubarak Bamualim

(al) Mizziy, Abu al Ḥajāj Yusuf, 1994, Tahdhīb al Kamāl, Beirut: Dār al Fikr.

(al) Uthaimin, Muhammad bin Solih, 2009, Taqrīb al Tadmuriyyah, Unaizah: Madār al Wațan. 